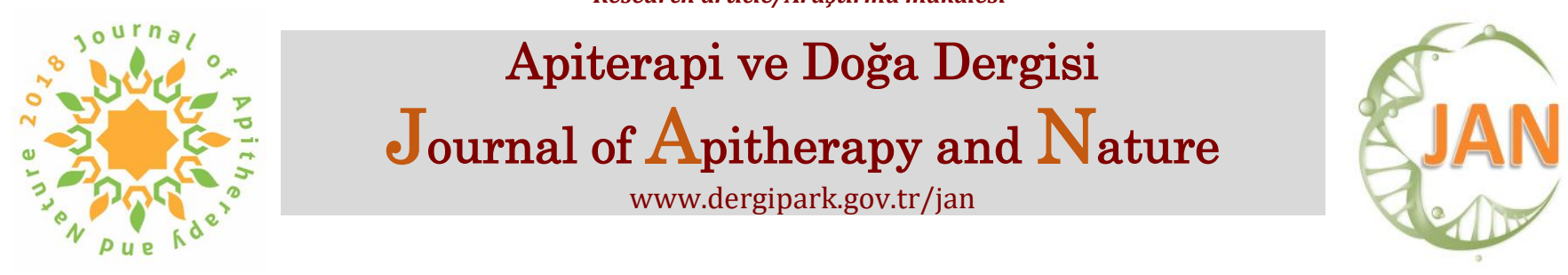

\title{
Isolation of Lignin-Degrading Bacteria from Different Sources and Testing of Their Ligninolytic Activities
}

\author{
Farklı Kaynaklardan Lignin Parçalayıcı Bakterilerin İzolasyonu ve Lignolitik \\ Aktivitelerinin Test Edilmesi
}

\section{Ayşegül OZER ${ }^{1}$, Erva RAKICI ${ }^{2}$, Kadriye INAN BEKTAS ${ }^{3}$,Sabriye CANAKCI $^{*}$, Ali Osman BELDUZ ${ }^{1}$}

\author{
${ }^{1}$ Department of Biology, Faculty of Sciences, Karadeniz Technical University, 61080 Trabzon-TURKEY \\ aysegulozer@trabzon.edu.tr, ORCID: 0000-0003-3437-2964 \\ sabriye@ktu.edu.tr, ORCID: 0000-0003-0132-7198 \\ belduz@ktu.edu.tr, ORCID: 0000-0003-2240-7568 \\ ${ }^{2}$ Pazar Vocational School, Recep Tayyip Erdoğan University, 53300 Rize-TURKEY \\ erva.esmer@erdogan.edu.tr, ORCID: 0000-0002-4464-4882 \\ ${ }^{3}$ Department of Molecular Biology and Genetic, Faculty of Sciences, Karadeniz Technical University, 61080 Trabzon- \\ TURKEY \\ inank@ktu.edu.tr, ORCID: 0000-0002-5909-588X
}

\section{Abstract}

Nine lignin-degrading bacteria were isolated from petroleum-contaminated soil and animal manure samples and characterized by $16 \mathrm{~S}$ rRNA sequence analysis. Three isolates were identified as Enterobacter cancerogenus, two as Enterobacter ludwigii, one as Citrobacter sedlakii, one as Citrobacter farmeri, one as Klebsiella pneumoniae, and one as Citrobacter murliniae. These bacteria used ligno sulphate as the sole carbon source but did not utilize kraft lignin (KL) as the sole source of carbon and energy. For this reason, basic nutrients, such as $1.0 \%$ glucose (w/v) and $0.5 \%$ peptone (w/v), were used as additional carbon and nitrogen sources to stimulate bacterial growth for KL decolorization. Under these conditions, the isolates Enterobacter cancerogenus L1, Enterobacter cancerogenus L2, Enterobacter ludwigii L3, Enterobacter ludwigii L4, Enterobacter cancerogenus PT21, Citrobacter farmari PT22, Citrobacter sedlakii PT41, Klebsiella pneumoniae $\mathrm{G} 1$, and Citrobacter murliniae C1 degraded kraft lignin by 37 \%, 14

\section{Özet}

Petrol bulaşmış toprak ve gübre örneklerinden dokuz adet lignin parçalayan bakteri izole edilmiş ve $16 \mathrm{~S}$ rRNA analizleri yapılmıștır. Bu izolatlardan üç tanesi Enterobacter cancerogenus, iki tanesi Enterobacter ludwigii, bir tanesi Citrobacter sedlakii, bir tanesi Citrobacter farmeri, bir tanesi Klebsiella pneumoniae, biri Citrobacter muryliniae olarak tanımlanmıştır. İzolatlar, tek karbon kaynağı olarak ligno sülfat kullanırken, tek karbon ve enerji kaynağı olarak kraft lignini (KL) kullanmamışlardır. $\mathrm{Bu}$ nedenle kraft lignin parçalanmasında bakteri çoğalmasını teşvik etmek için ilave karbon ve azot kaynakları olarak $\% 1.0$ glukoz $(\mathrm{a} / \mathrm{h})$ ve $\% 0.5$ pepton $(\mathrm{a} / \mathrm{a})$ gibi ek karbon ve azot kaynakları kullanılmıştır. $\mathrm{Bu}$ koşullar altında, Enterobacter cancerogenus L1, Enterobacter cancerogenus L2, Enterobacter ludwigii L3, Enterobacter ludwigii L4, Enterobacter cancerogenus PT21, Citrobacter farmari PT22, Citrobacter sedlakii PT41, Klebsiella pneumoniae G1 ve Citrobacter murliniae $\mathrm{C} 1$ izolatları ile kraft lignini sırasıyla 
$\%, 20 \%, 43 \%, 48 \%, 51 \%, 28 \%, 60 \%$, and $99 \%$, respectively. Remazol Brilliant Blue R (RBBR) decolorization potentials of the isolates were determined. The isolates were decolorized RBBR by 20-90 \% , respectively.

Keywords: Lignin, Bacteria, 16S rRNA, Decolorization
$\% \quad 37, \% \quad 14, \% \quad 20, \% \quad 43, \% \quad 48, \% \quad 51, \% \quad 28, \% 60$ ve\% 99 oranında parçalamışlardır. İzolatların ayrica Remazol Brilliant Blue R (RBBR) dekolorizasyon oranı analiz edilmiştir ve sirasiyla $\% \quad 20-90$ oranında RBRR dekolorizasyonu tespit edilmiştir.

Anahtar kelimeler: Lignin, Bakteri, 16S rRNA, Dekolorizasyon

Abbreviations: KL:Kraft Lignin, LiP: Lignin peroxidase, MnP: Manganese peroxidase

\section{INTRODUCTION}

The aromatic polymer lignin is well known for its resistance to microbial degradation because of its high molecular weight and the presence of various biologically stable carbon-to-carbon and ether linkages. The microorganisms that degrade plant lignin through an oxidative process are fungi (Tien \& Kirk, 1983), actinomycetes (Hernandez et al., 2001), and to a lesser extent, bacteria (Trojanowski et al., 1977). Among them, white rot fungi have attracted widespread attention because of their powerful lignindegrading enzymatic systems (Hatakka, 1994; Janusz et al., 2017). However, the use of fungi in industrial applications is not feasible due to the structural hindrance caused by fungal filaments; the requirement of particular culture conditions, such as humidity, aeration, temperature, and $\mathrm{pH}$, that are not compatible with industrial processing environments; the requirement of a long lag period, which thus results in very slow lignin degradation; the need for additional food sources, such as glucose and nitrogen, to support the fungal growth; and the instability of fungi in practical treatment under extreme environmental and substrate conditions, such as higher $\mathrm{pH}$, oxygen limitation, and high lignin concentrations
(Bholay et al., 2012). In contrast, bacteria are worth studying for their ligninolytic potential due to their immense environmental adaptability and biochemical versatility (Chandra et al., 2007).

The ligninolytic system is an extracellular enzymatic complex that includes peroxidases, laccases, and oxidases responsible for the production of extracellular hydrogen peroxide $\left(\mathrm{H}_{2} \mathrm{O}_{2}\right)$ (Ruiz-Duenas \& Martinez, 2009). Subject to the species, strains and culture conditions those enzymes display differential characteristics (Kirk \& Farrel, 1987). Ligninolytic enzymes have potential applications in a large number of fields, including the chemical, fuel, food, agricultural, paper, textile, cosmetic, and other industries (Maciel et al., 2010). The enzymes reported to be involved in bacterial lignin degradation are laccases, manganese peroxidase, lignin peroxidase, glutathione S-transferases, ringcleaving dioxygenases (Masai et al., 2003; Allocati et al., 2009), monooxygenases, and phenol oxidases (Perestelo et al., 1989). Such enzymes are also involved in degradation of polycyclic aromatic hydrocarbons (PAHs), which have the same structural properties and resistance to microbial degradation as lignin (Allocati et al., 2009; Perestelo et al., 1989). 
Dyes and dyestuff are also used in the textile, cosmetic, pharmaceutical, and leather industries but are of primary importance to textile manufacturing, the wastewater of which may contain a variety of these pollutants (McKay, 1979). The release of dyes has caused concern because of their environmental and health effects. Bioremediation is still seen as an attractive solution due to its reputation as a low-cost and environmentally friendly technology compared to chemical and physical treatment processes (Mc Mullan et al., 2001). As mentioned above, ligninolytic enzymes are used in dye decolorization; however, although bacteria are more efficient than fungi, the latter are widely used. For this reason, there is still a need for a continued search for more efficient ligninolytic bacterial strains for bioremediation and other applications (Raj et al., 2007). Therefore, in the present study, we isolated several bacterial strains which have a great lignin-degrading potential from fuel-contaminated soil and manure and we evaluated their dye decolorization and bioremediation capacity. The aim of this study is to determine the usability of isolated bacteria for various industries. Considering that alternative ways are being sought for mechanical and chemical methods used in waste dye decolorization and paper production, this study will contribute to the fulfillment of these needs.

\section{MATERIALS AND METHODS}

\subsection{Isolation of Lignin-Degrading Bacteria}

The contaminated soil and manure samples were collected with polyethelene bags from different areas in Arsin (Trabzon) were combined with lignin medium [(1-1): $5 \mathrm{~g}$ lignosulphonate, $9 \mathrm{~g}$ $\mathrm{NaCl}$ at $\mathrm{pH}$ 7.0] in a 250-ml Erlenmayer flask and then shaken at $37^{\circ} \mathrm{C}$ for 2 days to enrich the culture. After 2 days, the samples were inoculated into lignin agar plates that contained (1-1): $5 \mathrm{~g}$ lignin, $9 \mathrm{~g} \mathrm{NaCl}$, and $17 \mathrm{~g}$ agar at $\mathrm{pH}$ 7.0. This medium was used for screening the lignindegrading bacteria. The best lignin-degrading colonies were selected according to their colony morphology and their growth potential on lignin agar. Cells of ligninolytic strains were Gramstained using the method of Dussault (1955) and the Gram type was also determined using the KOH test (Powers, 1995). Cell morphology was examined by using phase-contrast microscopy (Nikon Eclipse E600; Olympus) on an exponentially growing liquid culture.

\subsection{DNA Isolation and 16S rRNA Gene Sequence Analysis}

The 16S rRNA genes were selectively amplified from purifed genomic DNA (according to the users manuel of Promega Wizard ${ }^{\circledR}$ Genomic DNA Purification Kit) with the use of oligonucleotide primers designed to anneal to conserved positions in the $3^{\prime}$ and 5' regions of the bacterial 16S rRNA genes. The forward primer, UNI16S-L(5'-

\section{ATTCTAGAGTTTGATCATGGCTTCA),} corresponded to positions 11 to 26 in Escherichia coli 16S rRNA, and the reverse primer, UNI16S$\mathrm{R}$

ATGGTACCGTGTGACGGGCGGTGTTGTA), corresponded to the complement of positions 
1411 to 1393 in Escherichia coli 16S rRNA (Somogyi, 1952). PCR reaction conditions were carried out according to Beffa et al. (1996), and the PCR product was cloned into the pGEM-T vector system. After the PCR amplification and the cloning of the $16 \mathrm{~S}$ rRNA genes of our isolates, the $16 \mathrm{~S}$ rRNA sequences were determined with the use of an Applied Biosystems 373A DNA sequencer with an ABI PRISM cycle sequencing kit (Macrogen, Holland). Sequences consisting of about $1400 \mathrm{nt}$ of $16 \mathrm{~S}$ rRNA genes were determined and compared with those in the EzTaxon database. The 16S rRNA gene sequences of the species most closely related to our isolates were retrieved from the database. The retrieved sequences were aligned with the use of the Clustal X program (Thompson et al., 1997) and manually edited. Phylogenetic trees were constructed by the neighbor-joining method with the use of the Molecular Evolutionary Genetics Analysis (MEGA) software version 4.0 (Tamura et al., 2007).

\subsection{Enzyme Assays}

For enzyme assays bacterial supernatant was used. The isolates were grown in lignin medium for seven days at $37^{\circ} \mathrm{C}$ and $120 \mathrm{rpm}$. Then the cultures were centrifuged at $10000 \mathrm{rpm}$ for 10 minutes and the bacterial supernatant was used as enzyme solution.

Laccase activity was determined by the oxidation of 2,2'azinobis - (3,ethylbenzthiazoline-6sulphonate) (ABTS). The reaction mixture contained $0.5 \mathrm{mM}$ ABTS, $0.1 \mathrm{M}$ sodium acetate buffer ( $\mathrm{pH}$ 5.0), and a suitable amount of enzyme. The oxidation of ABTS was followed by an absorbance increase at $420 \mathrm{~nm}$ (More et al., 2011).

Manganese peroxidase (MnP) activity was measured by monitoring the formation of Mn(III)-malonate complex at $270 \mathrm{~nm}$. The reaction mixtures contained $\mathrm{MnSO} 4(0.2 \mathrm{mM})$, $\mathrm{H} 202(0.1 \mathrm{mM})$, and enzyme in $50 \mathrm{mM}$ sodium malonate (pH 4.5) (Paice et al., 1993).

Lignin peroxidase (LiP) activity was measured by monitoring the oxidation of veratryl alcohol at $310 \mathrm{~nm}$. The reaction mixtures contained $50 \mathrm{mM} \mathrm{Na}$ tartrate buffer $(\mathrm{pH} 2.5$ or 4.5), $0.1 \mathrm{mM} \mathrm{H} 202$, and $2 \mathrm{mM}$ veratryl alcohol in a 1.0-ml reaction volume (Tien and Kirk, 1983).

\subsection{The Ratio of Lignosulphonate Degradation}

The percentage of lignosulphonate degradation of the isolates was tested in a 500-ml erlenmayer flask with $100 \mathrm{ml}$ of lignin degradation medium (LDM) consisting of (1-1): $1 \mathrm{~g} \mathrm{KH}_{2} \mathrm{PO}_{4}, 4 \mathrm{~g}$ $\mathrm{NaHPO}_{4}, 0.2 \mathrm{~g} \mathrm{NaCl}, 0.2 \mathrm{~g} \mathrm{MgSO}_{4} .7 \mathrm{H}_{2} \mathrm{O}, 0.05 \mathrm{~g}$ $\mathrm{CaCl}_{2}, 2 \mathrm{~g}$ yeast extract, and $5 \mathrm{~g}$ lignin. The sterilized medium was inoculated with $0.5 \mathrm{ml}$ of a 24-h culture of bacteria in nutrient broth. Controls consisting of uninoculated flasks were also prepared for comparison. The cultures were incubated for 1 week at $120 \mathrm{rpm}$ and $37^{\circ} \mathrm{C}$ (ElGammal et al., 1997).

After 1 week, the cultures were sterilized and passed through filter paper, the weight of which had been previously determined. After 
filtration, the papers were dried in Pasteur's furnace to determine the residual lignin ratio. The lignin degradation ratio of different isolates was expressed according to the following equation:

$$
L_{\mathrm{I}}-L_{\mathrm{F}}
$$

Degradation $(\%)=\frac{}{L_{\mathrm{I}}} \times 100$

where $L_{\mathrm{I}}=$ initial amount of lignin, and $L_{\mathrm{F}}=$ the amount of lignin after 1 week of culture.

\subsection{Kraft Lignin Decolorization}

Biodegradation experiments were carried out in 250-ml Erlenmayer flasks containing $100 \mathrm{ml}$ of sterile mineral salt medium (MSM, g 1-1: $2.4 \mathrm{~g}$ $\mathrm{Na}_{2} \mathrm{HPO}_{4}, 2 \mathrm{~g} \mathrm{~K}_{2} \mathrm{HPO}_{4}, 0.1 \mathrm{~g} \mathrm{NH}_{4} \mathrm{NO}_{3}, 0.01 \mathrm{~g}$ $\mathrm{MgSO}_{4}, 0.01 \mathrm{~g} \mathrm{CaCl}_{2}, 10 \mathrm{~g}$ D-glucose, $5 \mathrm{~g}$ peptone. The trace element solution $(1 \mathrm{ml} \mathrm{l-1,pH}$ 7.6) contained 2 g 1-1 kraft lignin. The sterilized medium was inoculated with $0.25 \mathrm{ml}$ of a $24-\mathrm{h}$ culture of bacteria in nutrient broth. The Control and inoculated erlenmayer flasks were incubated for six days in a rotary shaker at $120 \mathrm{rpm}$ under aerobic conditions at $30^{\circ} \mathrm{C}$ (Raj et al., 2006). The biodegradation of kraft lignin was determined in terms of the loss of total kraft lignin from the treated sample. Uninoculated (control) and bacteria-inoculated samples $\left(\begin{array}{lll}30 & \mathrm{ml}\end{array}\right)$ were centrifuged at $8,000 \mathrm{~g}$ for $15 \mathrm{~min}$ to remove biomass. Supernatants were acidified to $\mathrm{pH} 1-2$ with concentrated $\mathrm{HCl}$. The precipitate was collected in tared centrifuge tubes by centrifugation at $8,000 \mathrm{~g}$ for $30 \mathrm{~min}$, dried at $60 \pm$ $5^{\circ} \mathrm{C}$ for $48 \mathrm{~h}$, and then weighed. The kraft lignin loss $(\%)$ in the sample treated with bacteria was determined as dry weight (assuming kraft lignin present in identical volume of control as $100 \%$ ).

\subsection{Ligninolytic Activity Tests}

Isolates were subjected to different plate assays for screening of several lignin-degrading enzymes (laccase and peroxidase ( $\mathrm{LiP}$ and $\mathrm{MnP}$ ). An extracellular peroxidase ( $\mathrm{LiP}$ and $\mathrm{MnP}$ ) test was done according to a modification of the method proposed by Rayner \& Boddy (1988). The bacteria were grown on NA at $37^{\circ} \mathrm{C}$ for 2 days. The addition of equal parts of $0.4 \%(\mathrm{v} / \mathrm{v}) \mathrm{H}_{2} \mathrm{O}_{2}$ and $1 \%$ pyrogallol in water gave a yellow-brown color to colonies with peroxidase activity.

Laccase activity was determined with the use of ABTS agar. This colorless agar medium turns green due to the oxidation of ABTS (2,2'azino-bis(3-ethylbenzthiazoline-6-

sulphonate) to ABTS-azine in the presence of laccase. For preparation of ABTS agar LME basal medium ( $\mathrm{g}-1$ in distilled water: $1 \mathrm{~g}$ $\mathrm{KH}_{2} \mathrm{PO}_{4}, 0.5 \mathrm{~g} \mathrm{C}_{4} \mathrm{H}_{12} \mathrm{~N}_{2} \mathrm{O}_{6}, 0.5 \mathrm{~g} \mathrm{MgSO}_{4} \bullet 7 \mathrm{H}_{2} \mathrm{O}$, 0.01 g Yeast Extract, 0.001 g CuSO $_{4} .5 \mathrm{H}_{2} \mathrm{O}, 0.001$ g $\mathrm{Fe}_{2}\left(\mathrm{SO}_{4}\right)_{3}, \quad 0.01 \mathrm{~g} \quad \mathrm{CaCl}_{2} \cdot 2 \mathrm{H}_{2} \mathrm{O}, \quad 0.001 \mathrm{~g}$ $\mathrm{MnS}_{4} \cdot \mathrm{H}_{2} \mathrm{O}$ ) medium supplemented with $0.1 \%$ w/v ABTS and $1.6 \% \mathrm{w} / \mathrm{v}$ agar and autoclave. To every $100 \mathrm{ml}$ of the growth medium prepared, 1 $\mathrm{ml}$ of a separately sterilized $20 \%$ (w/v) aqueous glucose solution was aseptically added. The production of laccase was shown by the formation of a green color in the growth medium.

\subsection{Utilization of Lignin Monomers}

To monitor the growth on lignin monomers, a mineral medium (MM: g-1 in distilled water: 1.55 
g $\quad \mathrm{KH}_{2} \mathrm{PO}_{4}, \quad 0.85 \quad \mathrm{~g} \quad \mathrm{NaH}_{2} \mathrm{PO}_{4} .2 \mathrm{H}_{2} \mathrm{O}, \quad 2 \quad \mathrm{~g}$ $\left(\mathrm{NH}_{4}\right)_{2} \mathrm{SO}_{4}, 0.1 \mathrm{~g} \mathrm{MgCl}_{2} .6 \mathrm{H}_{2} \mathrm{O}, 10 \mathrm{mg}$ EDTA and $5 \mathrm{ml}$ trace element solution) was supplemented with $5 \mathrm{mM}$ lignin monomers (vanilic acid, vanillin, 4-hydroxybenzoic acid, syringic acid, phenol, veratryl alcohol, guaiacol) as the sole carbon and energy source. Growth was considered positive if observed after successive transfers to fresh medium (Bogdan et al., 2018).

\subsection{Decolorization of Azo,} Triphenylmethane and Heterocyclic Dyes

The decolorization of dyes was monitored at the maximum visible absorbance of each dye. Unless otherwise stated, the reaction mixture consisted of $80 \mu \mathrm{M}$ of dye (see Table 1), $0.1 \mathrm{U}$ of lignin peroxidase, and $0.4 \mathrm{mM}$ of $\mathrm{H}_{2} \mathrm{O}_{2}$ in $50 \mathrm{mM}$ sodium tartrate in a total volume of $1 \mathrm{ml}$. The reaction was initiated by the addition of $\mathrm{H}_{2} \mathrm{O}_{2}$, and absorbance was measured $15 \mathrm{~min}$ after the initiation (Ollikka, 1993).

Table 1. Conditions for dye decolorization by lignin preoxidase

\begin{tabular}{ll}
\hline \multicolumn{1}{c}{ Dye } & Absorbance maximum \\
\hline BPB & 590 \\
Methylene blue & 662 \\
Methyl orange & 502 \\
Toluidine blue & 625 \\
Malachite green & 620 \\
\hline
\end{tabular}

\subsection{Dye Decolorization Determination}

The dye decolorization by the isolated microorganisms was tested in $250 \mathrm{ml}$ erlenmayer flasks with $25 \mathrm{ml}$ of basal liquid medium (BLM) consisting of (1-1): $10 \mathrm{~g}$ glucose, $5 \mathrm{~g}$ peptone, $2 \mathrm{~g}$ yeast extract, and $70 \mathrm{ml}$ of trace element solution (in $\mathrm{g}$ 1-1: $1.5 \mathrm{~g}$ nitrilacetic acid at $99 \%, 3 \mathrm{~g}$ $\mathrm{MgSO}_{4} \cdot 7 \mathrm{H}_{2} \mathrm{O}, 0.5 \mathrm{~g} \mathrm{MnSO}_{4} \cdot \mathrm{H}_{2} \mathrm{O}, 1 \mathrm{~g} \mathrm{NaCl}, 0.1$ $\mathrm{g} \mathrm{FeSO}_{4} \cdot 7 \mathrm{H}_{2} \mathrm{O}, 0.1 \mathrm{~g} \mathrm{CoSO}_{4}, 0.1 \mathrm{~g} \mathrm{CaCl}_{2} \cdot 2 \mathrm{H}_{2} \mathrm{O}$, $0.1 \mathrm{~g} \mathrm{ZnSO}_{4} \cdot 7 \mathrm{H}_{2} \mathrm{O}, 0.01 \mathrm{~g} \mathrm{CuSO}_{4} \cdot 5 \mathrm{H}_{2} \mathrm{O}, 0.01 \mathrm{~g}$ $\mathrm{AlK}\left(\mathrm{SO}_{4}\right)_{2} \bullet 12 \mathrm{H}_{2} \mathrm{O}, 0.01 \mathrm{~g} \mathrm{H}_{3} \mathrm{BO}_{3}$, and $0.01 \mathrm{~g}$ $\mathrm{Na}_{2} \mathrm{MoO}_{4} \cdot 2 \mathrm{H}_{2} \mathrm{O}$ ) supplemented with $200 \mathrm{mg} \mathrm{1-1}$ of Remazol Brilliant Blue R (RBBR). The sterilized medium was inoculated with $0.25 \mathrm{ml}$ of a 24-h culture of bacteria in nutrient broth. Controls consisting of uninoculated flasks were also prepared for comparison. Triplicate flasks were used for each isolate and control. The cultures were incubated for 7 days at $120 \mathrm{rpm}$ and $37^{\circ} \mathrm{C}$ and then centrifuged at $13,000 \times \mathrm{g}$ for $5 \mathrm{~min}$ at $4^{\circ} \mathrm{C}$. The cell-free supernatant color was read with a spectrophotometer at the maximum absorbance spectra $(\lambda \max )$ of the dyes used, i.e., $595 \mathrm{~nm}$ for rbbr. the uninoculated dye-free medium was used as blank. the uninoculated dyecontaining controls were used as reference to correct abiotic color disappearance (Chantarasiri and Boontanom, 2017). The decolorization efficiency of different isolates was expressed according to the following equation:

decolorization $(\%)=\frac{A_{\lambda} \text {, initial }-A_{\lambda}, \text { final }}{A_{\lambda} \text {, initial }} \times 100$

where $a \lambda$, initial $=$ initial absorbance; and $\mathrm{a} \lambda$, final $=$ absorbance after 7 days of culture. 


\section{RESULTS AND DISCUSSION}

\subsection{Ligninolytic Microorganisms}

As a result of isolation and screening, nine lignindegrading bacteria were selected on the basis of their growth degree on lignin agar. The medium contained lignin as the sole carbon source. The isolates designated as L1, L2, L3, L4, PT21, PT22, PT41, G1, and C1 used lignin as the carbon source and developed colonies within $24 \mathrm{~h}$ of incubation. The cells of the strains were gramnegative and rod-shaped. The isolate G1 had a bacterial capsule. On the agar plates, all isolates had white and mucoid colonies.

\subsection{S rRNA Gene Sequence Analysis}

A total of 1400 nucleotides of the 16S rRNA from 9 isolates were aligned and compared to sequences of related bacteria. A phylogenetic tree was constructed with the use of the neighborjoining method (Figure 1). On the basis of the 16S rRNA gene sequence analysis, the isolates were identified as members of the Enterobacteriaceae family. Five of them belong to the genus of Enterobacter, three to the genus Citrobacter, and one to the genus Klebsiella. The accession numbers of the 16S rRNA gene sequences of the 9 isolates had been assigned by GenBank (Tables 2 and 3). According to the data obtained, the isolates L1, L2, and PT21 are different strains of Enterobacter cancerogenus; L3 and L4 are different strains of Enterobacter ludwigii; PT22 is a strain of Citrobacter farmeri $\mathrm{C} 1$ is a strain of Citrobacter murliniae; PT41 is a strain of Citrobacter sedlakii and G1 is a strain of Klebsiella pneumoniae.

Table 2. The percentage similarity of $16 \mathrm{~S}$ rRNA of Enterobacter species and the isolates

\begin{tabular}{llllll}
\hline & L1 & L2 & L3 & L4 & PT21 \\
\hline $\begin{array}{l}\text { Enterobacter } \\
\text { cancerogenus }\end{array}$ & 99 & 98,8 & 96,6 & 98,9 & 98,7 \\
$\begin{array}{l}\text { Enterobacter } \\
\text { asburiae }\end{array}$ & 98,6 & 98,2 & 96,5 & 98,4 & 98 \\
$\begin{array}{l}\text { Enterobacter } \\
\text { ludwigii }\end{array}$ & 98,5 & 98 & 97,3 & 99,7 & 97,8 \\
$\begin{array}{l}\text { Enterobacter } \\
\text { cowanii }\end{array}$ & 97 & 98,1 & 95,7 & 97,7 & 98,2 \\
\hline
\end{tabular}

Table 3. The percentage similarity of $16 \mathrm{~S}$ rRNA of Citrobacter and Klebsiella species and the isolates

\begin{tabular}{lllll}
\hline & PT22 & PT41 & C1 & G1 \\
\hline Citrobacter sedlakii & 97,2 & 99,2 & & \\
Citrobacter farmeri & 99,2 & 98,1 & & \\
Citrobacter rodentium & 97,8 & 98,4 & & \\
\hline Citrobacter murliniae & & & 97,4 & \\
\hline Klebsiella pneumoniae & & & & 99,8 \\
Klebsiella variicola & & & & 99 \\
Klebsiella & & & & 98 \\
granulomatis & & & & \\
\hline
\end{tabular}

\subsection{Lignin Degradation}

Figure 2 shows the rate of lignosulphonate degradation after one week of incubation. As shown in the figure, the lignin degradation of the isolates is considerably high. Lignins are very complex natural polymers with many random couplings, but their exact chemical structure is not known. The physical and chemical properties of lignin differ depending on the extraction technology. For example, whereas lignosulphonates are hydrophilic (dissolve in water), kraft lignins are hydrophobic (do not dissolve in water). However, the kraft lignin is very important in the paper and pulp industry. Thus, the kraft lignin degradation of the isolates was investigated in this study. The isolates do not 


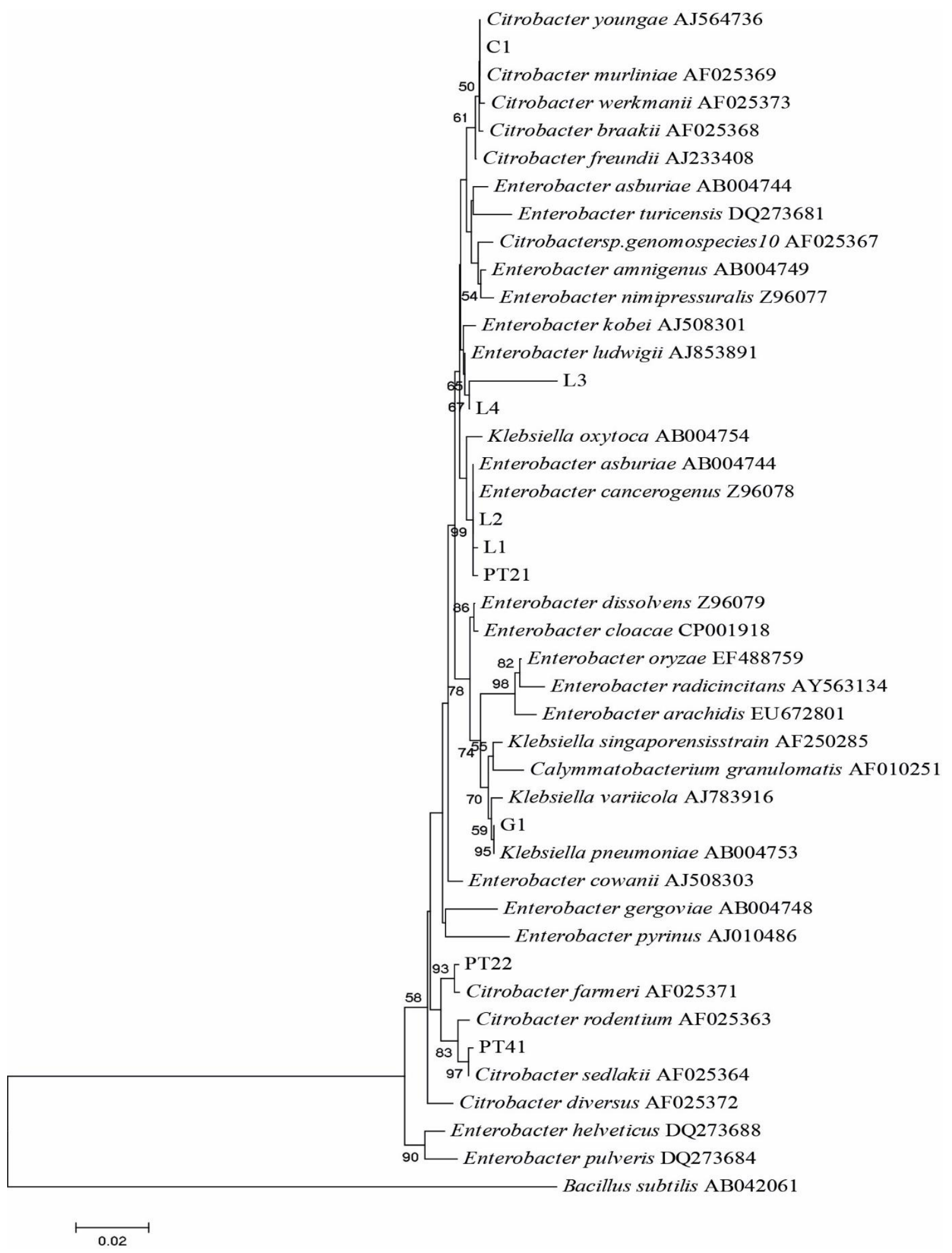

Figure 1. Dendrogram estimated phylogenetic relationship on the basis of 16S rRNA gene sequence data of the bacteria isolated from different sources and some reference strains, using the neighbor-joining method. The accession numbers are given in parentheses. The scala bar represents $2 \%$ divergence. 
use kraft lignin as the sole carbon source. For this reason, basic nutrients, such as $1.0 \%(\mathrm{w} / \mathrm{v})$ glucose and $0.5 \%(\mathrm{w} / \mathrm{v})$ peptone, were used as additional carbon and nitrogen sources to stimulate bacterial growth for KL decolorization.

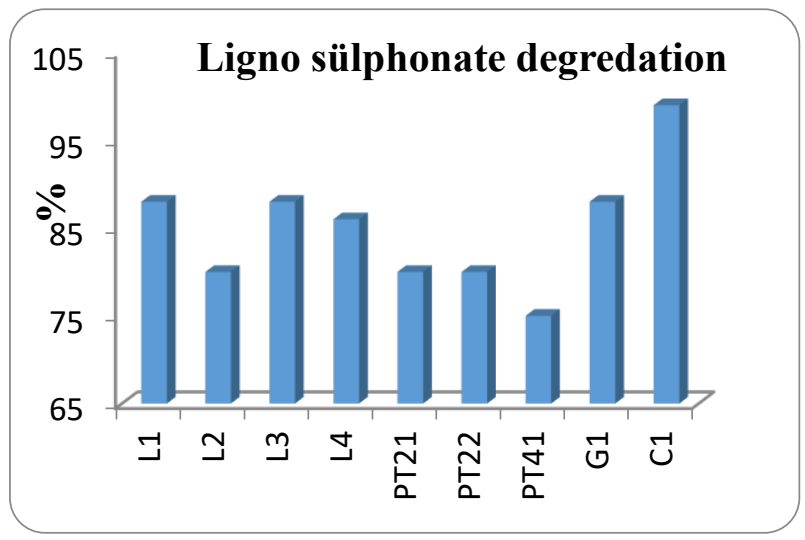

Figure 2. The percentage of lignin biodegradation

Figure 3 provides the data obtained from the kraft lignin biodegradation. The results are in accordance with those obtained by El-Hanafy et al. (2008) but are much better because the KL concentration is higher. El-Hanafy et al. (2008) found that the isolated strains BahHAE3 and BahHAE8 reached a maximum lignin degradation of $76.3 \%$ and $67.1 \%$, respectively, on the sixth day. The lignin concentration in our study $(2 \mathrm{~g}$ lignin/l) is much higher than the $0.7 \mathrm{~g}$ used by Chandra et al. (2007), who reported that Paenibacillus $\quad$ sp., $\quad$ Aneurinibacillus aneurinilyticus, and Bacillus sp. achieved lignin degradation rates of 37,33 , and $30 \%$, respectively, during the incubation period.

Deschamps et al. (1980) used an industrial kraft lignin (1 $\mathrm{g}$ lignin/l) as the sole carbon source in their study. They found that Aeromonas sp. degraded $98 \%$ of the kraft lignin after 5 days of incubation. The differences in the lignin degradation rates obtained between previous studies could be explained by the variations in bacterial strains, incubation conditions, and lignin structures used.

The results of the current study support the finding that many bacterial strains degrade and assimilate lignin (Chandra et al., 2007; Bal et al., 1989; Nishimura et al., 2006; Odier et al., 1981; Pometto et al., 1986). Furthermore, the capability of the soil-isolated bacteria to effectively degrade and assimilate lignin as the sole carbon source complied with the findings of Morii et al. (1995), who reported that three bacterial species isolated from compost soil, namely, Azotobacter, Bacillus megatarium, and Serretia marcescens, are capable of degrading lignin. Regarding the Enterobacter species isolated in the current study, many studies have pointed out the ability of the species to degrade lignin (Chandra et al., 2007; Morii et al., 1995).

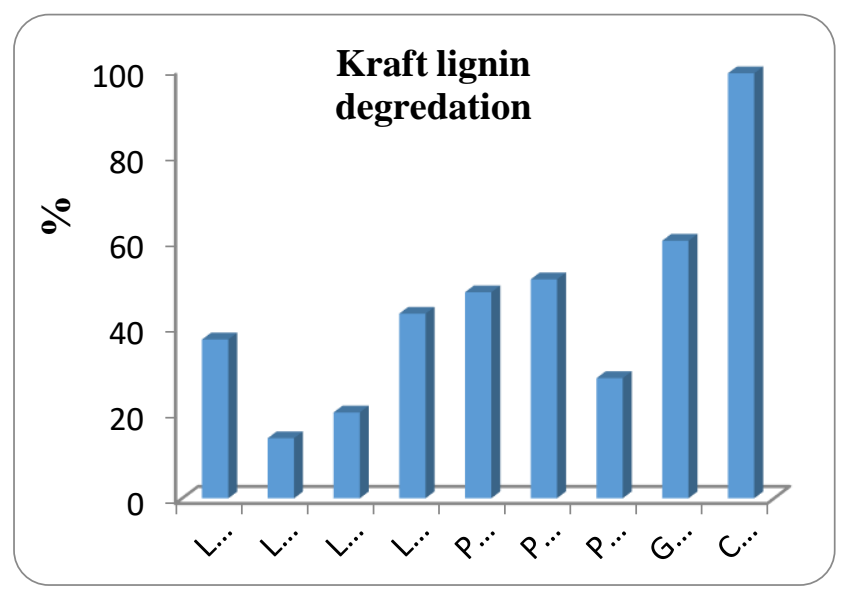

Figure 3. The percentage of kraft lignin biodegradation 


\subsection{Ligninolytic Enzymes of The Isolates}

In this study, all the isolates showed extracellular peroxidase activity. To determine whether the peroxidase was $\mathrm{MnP}$ or LiP, enzyme assays were done. With the use of spectrophotometric methods, we determined that the isolates showed lignin peroxidase activity. Only the $\mathrm{C} 1$ isolate showed manganese peroxidase activity.

According to the ABTS agar laccase test, only the isolate PT41 showed laccase activity. As a result, the isolated bacterium Citrobacter sedlakii PT41 contained both laccase and lignin peroxidase. Previous studies have reported that the Bacillus species contains laccase (Canas et al., 2007; Reiss et al., 2011; Franc et al., 2001); in addition, Oliviere at al. (2009) found that Bacillus pumilus and Paenibacillus sp. contain manganese peroxidase. The Streptomyces species has also been found to contain lignin peroxidase (Gottschalk et al., 1999; Nascimento \& Silva, 2008).

\subsection{Utilization of Lignin Monomers}

There is a wide spectrum of lignin monomers that could be used to stimulate the growth of the isolates Enterobacter cancerogenus L1, Enterobacter cancerogenus L2, Enterobacter ludwigii L3, Enterobacter cancerogenus PT21, and Citrobacter sedlakii PT41 (Table 4). In this study, these isolates used all of the tested monomers in their growth. C1 was the only isolate that did not grow on vanillic acid; neither did it grow on vanillin and 4-hydroxybenzoic acid. Enterobacter ludwigii L4, Citrobacter farmeri PT22, and Klebsiella pneumoniae G1 also did not grow on vanillin. Remarkably, the isolated strains have the ability to oxidize aromatic alcohols or aldehydes to their corresponding carboxylic acid form. Bandounas et al. (2011) found that the spectrum of lignin monomers that could be utilized for growth was relatively limited for all of the isolates and that the alcoholic forms of the aromatic monomers (veratryl alcohol and guaiacol) were not metabolized by any of the isolates. In contrast, the isolates in this study metabolized the aromatic monomers well.

\subsection{Decolorization of Azo, Triphenylmethane and Heterocyclic Dyes}

In this study, we examined the decolorization of several dyes by crude lignin peroxidase. Only the lignin peroxidase obtained from Klebsiella pneumoniae G1 decolorized dyes significantly. It decolorized BPB, methylene blue, methyl orange, and toloudine blue by $70 \%, 40 \%, 19 \%$, and $58 \%$, respectively (Figure 4). These results are in accordance with those obtained by Ollikka et al. (1993), who tested the dye decolorization of Phanerochaete chrysosporium and found that the best decolorization (93\%) was obtained for bromophenol blue, as shown in this study. Ollikka et al. found that the decolorization ability of the enzymes was increased when veratryl alcohol was present in the reaction mixtures. In the present study, veratryl alcohol was not used in the reaction mixtures. Taking into consideration the previous findings, we can predict that the 
Table 4 : Growth of bacterial isolates on lignin monomers

\begin{tabular}{|c|c|c|c|c|c|c|c|c|c|}
\hline Aromatic compound & $\mathbf{L} 1$ & $\mathbf{L 2}$ & $\mathbf{L 3}$ & L4 & PT21 & PT22 & PT41 & G1 & C1 \\
\hline Vanilic acid & + & + & + & + & + & + & + & + & - \\
\hline Vanilin & + & + & + & - & + & - & + & - & - \\
\hline 4-Hydroxybenzoic acid & + & + & + & + & + & - & + & + & - \\
\hline Syringic acid & + & + & + & + & + & + & + & + & + \\
\hline Phenol & + & + & + & + & + & + & + & + & + \\
\hline Veratryl alcohol & + & + & + & + & + & + & + & + & + \\
\hline Guaiacol & + & + & + & + & + & + & + & + & + \\
\hline
\end{tabular}

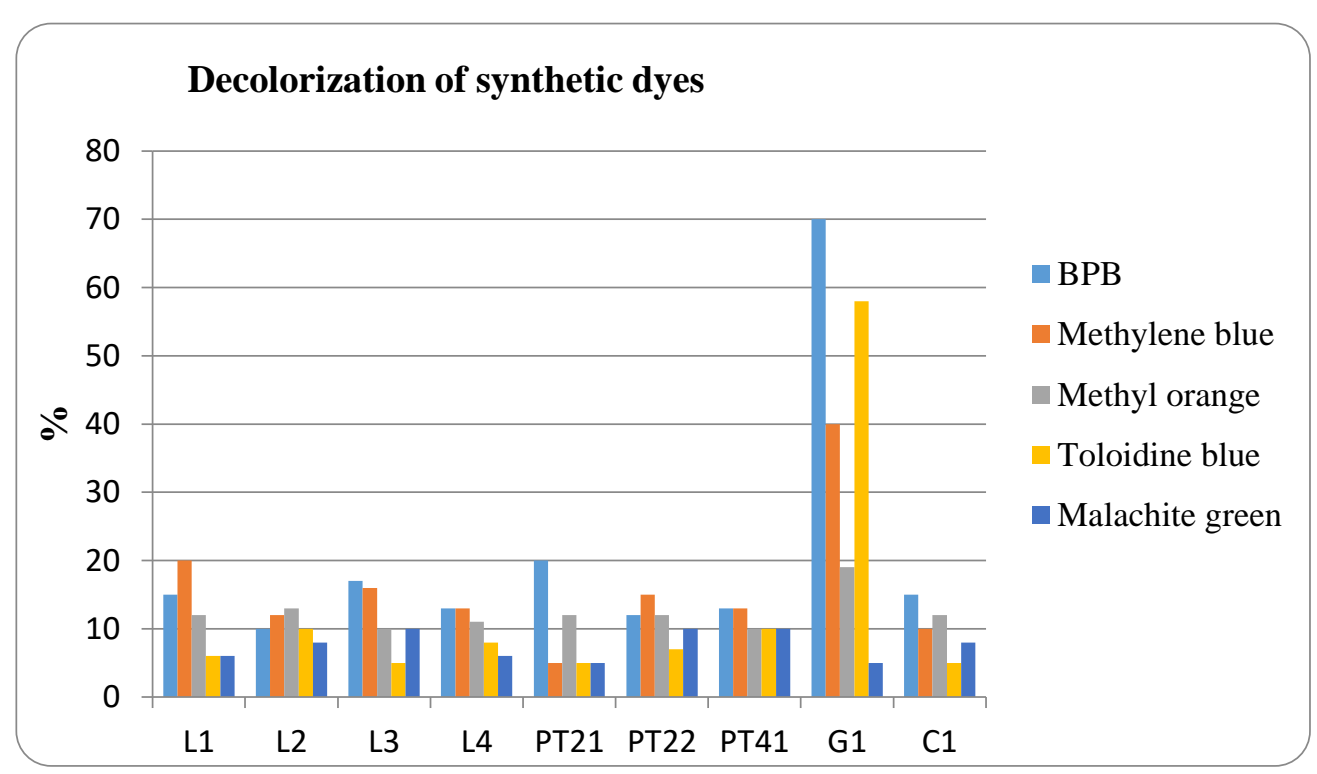

Figure 4. The percentage of dye decolorization 
decolorization capacity of Klebsiella pneumoniae G1 lignin peroxidase will be increased.

\subsection{Dye Decolorization Studies}

The nine isolates were further tested by measuring their efficiency of RBBR decolorization (Figure 5). All of the strains were able to decolorize RBBR to some extent, and four of them achieved a $90 \%$ decrease in dye color. In the present study, this showed that the ability to decolorize RBBR dye is correlated to ligninase production. Previous works also found a correlation between decolorization of polymeric dyes and lignin degradation activity among several wood- or soil-inhabiting fungi (Falcon et al., 1995; Pasti and Crawford, 1991). However, there are very few studies about such correlation among bacteria. In this research, we showed that some bacteria have as much ability to degrade polymeric dyes as fungi.

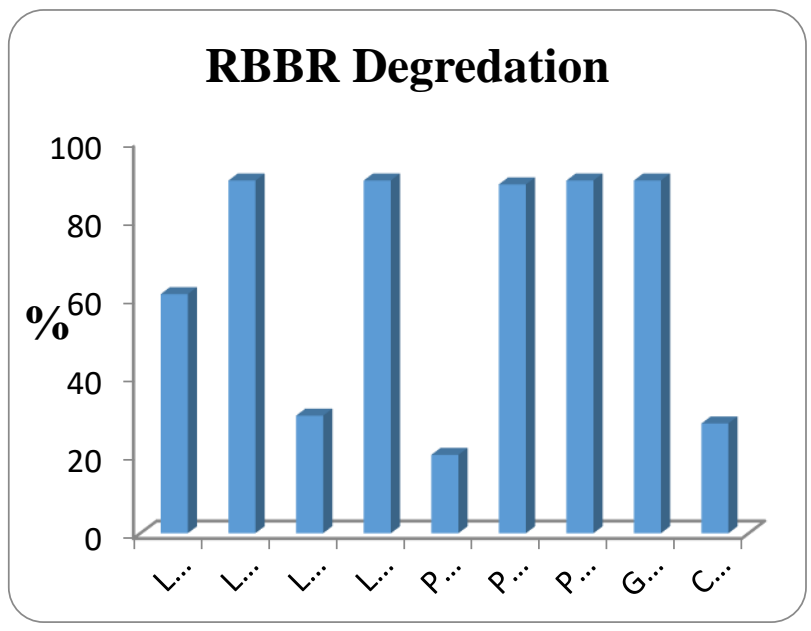

Figure 5. The percentage of RBBR degradation

M. J. Lopez et al. (2006) tested the dye decolorization of bacteria and fungi that they had isolated, and they found that RBBR was difficult to decolorize. Twenty-five strains showed some decolorization of RBBR, but the efficiency was around 15-30\% except for three mesophilic fungi, whose decolorization rates were greater than 50\%. Rodriguez et al. (1999) found that Pleurotus ostreatus strains exhibited high laccase and manganese peroxidase activity and decolorized different industrial dyes very efficiently. An earlier study by Özsoy et al. (2005) revealed that F. trogii could effectively decolorize RBBR dye by up to $90 \%$ within $24 \mathrm{~h}$. They used an initial dye concentration of about 10-50 mg/l, compared to the RBBR concentration of $200 \mathrm{mg} / \mathrm{l}$ used in this study. Kiran et al. (2019) found that when synthetic dye wastewater concentration was increased from $0.01-0.05 \%$, the percent decolourization decreased from $80.93 \%$ to $24.705 \%$. Taking into consideration these previous findings and the dye concentration, we can say that our isolates were more effective at dye decolorization.

In conclusion, many lignin-degrading organisms are reported in this study, as are their lignin degradation and dye decolorization rates. The isolation and identification of environmentally friendly bacteria for lignin degradation have become essential because all previous researchers concentrated on the use of fungal treatments. The importance of ligninolytic bacteria has increased because lignin-degrading bacteria have a wider tolerance for temperature differences, $\mathrm{pH}$ variations, and oxygen limitation compared to fungi. This study found that the strains Klebsiella pneumoniae G1 and $\mathrm{C} 1$ have a strong potential for KL degradation. In particular, 
the Klebsiella pneumoniae G1 strain is very effective in RBBR decolorization. Additional studies have to be made to determine the optimum conditions (nutrients, temperature, etc.) for maximum lignin degradation and dye decolorization by pure or mixed cultures of the strains. In addition, ligninolytic enzymes from these strains could be extracted and evaluated.

\section{REFERENCES}

Allocati, N., Federici, L., Masulli, M. \&Di Ilio, C. (2009) Glutathione transferases in bacteria. The FEBS Journal, 276(1), 58-75.

Bal, A.S., Betts, W.B. \& McCarthy, A.G. (1989) Degradation of lignin-related compounds by Actinomycetes. Appl. Environ. Microbiol., 55, 1642-1646.

Bandounas, L., Wierckx, N., Winde, J. \& Ruijssenaars, H.J. (2011) Isolation and characterization of novel bacterial strains exhibiting ligninolytic potential. $B M C$ Biotechnology, 11(94).

Beffa, T., Blanc, M., Lyon, P.F., Vogt, G., Marchiani, M., Fischer, J.L. \& Aragno, M. (1996) Isolation of Thermus Strains from hot composts. Appl. Environ. Microbiol., 62, 1723-1727.

Bholay, A.D., Borkhataria Bhavna, V., Jadhav Priyanka, U., Palekar Kayeri, S., Dhalkari Mayuri, V. \& Nlawade, P.M. (2012) Bacterial lignin peroxidase: A tool for bioleaching and biodegradation of industrial effluents. Universal journal of Environmental Research and Technology, 2(1), 58-64.

Canas, A.I., Alcalde, M., Plou, F., Martinez, F.J., Martinez, A.T. \& Camerero, S. (2007) Transformation of polycyclic aromatic hydrocarbons by laccase is strongly enhanced by phenolic compounds present in soil. Environmental Science \& Technology, 41(8), 2964-2971.

Chandra, R., Raj, A., Purohit, H.J. \& Kapley, A. (2007) Characterization and optimization of three potential aerobic bacterial strains for kraft lignin degradation from pulp paper waste. Chemosphere, 67 (4), 839-846.

Deschamps, A.M., Mahoudeau, G. \& Lebeault, J.M. (1980) Fast degradation of Kraft lignin by bacteria. Appl. Microbiol. Biotechnol., 9, 45-51.

EL-Hanafy, A.A., Abd-Elsalam, H.E. \& Hafez, E.E. (2008). Molecular characterization of two native Egyptian ligninolytic bacterial strains. $J$. Appl. Sci. Res., 4(10), 1291-1296.

Falcon, M.A., Rodriguez, A., Carnicero, A., Regalado, V., Perastelo, F., Milstein, O. \& Fuente, G. (1995) Isolation of microorganisms with lignin transformation potential from soil of Tenerife Island. Soil Biol. Biochem., 27, 121-6.

Franc, M., Hullo, O., Moszer, I., Danchin, A. \& Martin-Verstraete, I. (2001) CotA of Bacillus subtilis is a copper-dependent laccase. Journal of Bacteriology, 183(18), 5426-5430. 
Gottschalk, M.F., Macedo, M.B. \& Bon, P.S. (1999) Lignin peroxidase production by Streptomyces viridosporus T7A use of corn oil as a carbon source. Applied Biochemistry and Biotechnology, 77(79). 771-778.

Hatakka, A. (1994) Lignin-modifying enzyme from selected white-rot fungi: production and role in lignin degradation. FEMS Microbiology Review, 13, 125-135.

Hernandez, M., Hernandez-Coronado, M.J., Montiel, M.D., Rodriquez, J. \& Arias, M.E. (2001) Analysis of alkali-lignin in a paper mill effluent decolorised with two Streptomyces strains by gas chromatography-mass spectrometry after cupric oxide degradation. J. Chromatogr., 919, 389-394.

Janusz, G., Pawlik, A., Sulej, J, Swiderska-Burek, U., Jarosz-Wilkolazka, A \& Paszczynski, A. (2017) Lignin degradation: microorganisms, enzymes involved, genomes analysis and evolution. FEMS Microbiol. Rev., 41(6), 941962.

Kiran, S., Huma, T., Jala, F, Farooq, T., Hameed, A., Gulzar, T., Bashir, A., Rahmat, M., Rahmat, R. \& Rafique, M.A. (2019) Lignin degrading system of Phanerochaete chrysosporium and its exploitation for degradation of synthetic dyes wastewater. Pol. J. Environ. Stud. 28 (3), 17491757.
Kirk, T.K. \& Farrell, R.L. (1987) Enzymatic "combustion": The microbial degradation of lignin. Annual Review of Microbiology, 41(1), 465-501.

Lopez, M.J., Guisado, G., Vargas-Garcia, M.C., Suarez-Estella, F. \& Moreno, J. (2006) Decolorization of industrial dyes by ligninolytic microorganisms isolated from composting environment. Enzyme and Microbial Technology, $40,42-45$.

Maciel, M.J.M., Silva, A.C. \& Ribeiro, H.C.T. (2010) Industrial and biotechnological applications of ligninolytic enzymes of the basidiomycota: A review. Enviromental Biotechnology, 13(6), 14-15.

Masai, E., Ichhimura, A., Sato, Y., Miyauchi, K., Katayama, Y. \& Fukuda, M., 2003. Roles of the enantioselective glutathione S-transferase in cleavage of beta-aryl ether. Journal of Bacteriology, 185(6), 1768-1775.

McKay, G. (1979) Waste colour removal from textile effluents. Am. Dyes. Rep., 68, 29-36.

McMullan, G., Meehan, C., Conneely, A., Kirby, N., Robinson, T., Nigam, P., Banat, I.M., ... Smyth, W.F. (2001) Microbial decolourisation and degradation of textile dyes. Appl. Microbiol. Biotechnol., 56, 81-87.

More, S., Renuka, P.S., Pruthvi, K., Swetha, M, Malini, S. \& Veena S.M. (2011) Isolation, 
purification and characterization of fungal laccase from Pleurotus sp. Enzyme Research, 2011, 7.

Morii, H., Nakamiya, K. \& Kinoshita. S. (1995) Isolation of lignin decolouring bacterium. $J$. Ferment. Bioeng., 80, 296-299.

Nascimento, H.J. \& Silva, E.J.G. (2008) Purification of lignin peroxidase isoforms from Streptomyces viridosporus T7A by hydrophobic based chromatographies. World J. Microbiol. Biotechnol., 24, 1973-1975.

Nishimura, M., Ooi, O. \& Davies, J. (2006) Isolation and characterization of Streptomyces $\mathrm{sp}$. NL15-2K capable of degrading lignin-related aromatic compounds. J. Biosci. Bioeng., 102, 124-127.

Odier, E., Janin, G. \& Monties, B. (1981) Poplar lignin decomposition by gram-negative aerobic bacteria. Appl. Environ. Microbiol., 41, 337-341.

Oliveira, P., Duarte, M.C.T., Ponezi, A.N. \& Durrant, L.R. (2009) Purification and partial characterization of manganese peroxidase from Bacillus pumilus and Paenibacillus sp. Brazilian Journal of Microbiology, 40, 818-826.

Ollikka, P., Alhonmaki, K., Leppanen, V.M., Glumoff, T., Raijola, T. \& Suominen, I. (1993) Decolorization of azo, triphenyl methane, heterocyclic and polymeric dyes by lignin peroxidase isoenzymes from Phanerochaete chrysosporium. Appl. Environ. Microbiol., 59(12), 4010-4016.

Özsoy, D.H., Ünayar, A. \& Mazmanc1, M.A. (2005) Decolourisation of reactive textile dyes Drimarene Blue X3LR and Remazol Brillant Blue $\mathrm{R}$ by Funali trogii ATCC200800. Biodegradation, 16, 195-204.

Paice, M.G., Reid, I.D., Bourbonnais, R., Archibald, F.S. \& Jurasek, L. (1993) Manganese peroxidase, produced by Trametes versicolor during pulp bleaching, demethylates and delignifies kraft pulp. Applied and Environmental Microbiology, 59(1), 260-265.

Pasti, M.B. \& Crawford, D.L. (1991) Relationships between the abilities of streptomycetes to decolorize three anthron-type dyes and to degrade lignocellulose. Can. J. Microbiol., 37, 902-907.

Perestelo, F., Falcon, M.A., Perez, M.L., Roig, E.C. \& Martin, G.F. (1989) Bioalteration of kraft pine lignin by bacillus megaterium 1solated fromcompost piles. J. Fermen. Bioeng., 68(2), 151-153.

Pometto, A.L. \& Crawford, D.L. (1986) Effect of $\mathrm{pH}$ on lignin and cellulose degradation by Streptomyces viridosporus. Appl. Environ. Microbiol., 52, 246-250.

Raj, A., Chandra, R., Reddy, M.M.K., Purohit, H.J. \& Kapley, A. (2007) Biodegradation of kraft 
lignin by newly isolated bacterial strain, Aneurinibacillus aneurinilyticus from the sludge of a pulp paper mill. World J. Microbiol. Biotechnol., 23, 793-799.

Rayner, A.D.M. \& Boddy, L. (1988) Fungal decomposition of wood. Its biology and ecology. Wiley, New York.

Reiss, R., Ihssen, J. \& Thöny-Meyer, L. (2011) Bacillus pumilus laccase: a heat stable enzyme with a wide substrate spectrum. $B M C$ Biotechnology, 11(9).

Rodriguez, E., Pickard, M.A. \& Vazquez-Duhalt, R. (1999) Industrial dye decolorization by laccases from ligninolytic fungi. Current Microbiol., 38, 27-32.

Ruiz-Dueñas, F.J. \& Martínez, A.T. (2009) Microbial degradation of lignin: how a bulky recalcitrant polymer is efficiently recycled in nature and how we can take advantage of this. Microbial Biotechnology, 2(2). 164-177.
Somogyi, M. (1952) Notes on sugar determination. J. Biol. Chem., 195, 19-23.

Tamura, K., Dudley, J., Nei, M. \& Kumar, S. (2007) MEGA4: molecular evolutionary genetics analysis (MEGA) software version 4.0. Mol. Biol. Evol., 24, 1596-1599.

Thompson, J.D., Gibson, T.J., Plewniak, F., Jeanmouqin, F. \& Higgins, D.G. (1997) The ClustalX window interface: flexible strategies for multiple sequence alignment aided by quality analysis tools. Nucleic Acids Res., 24, 4876-4882.

Tien, M. \& Kirk, T.K. (1983) Lignin-degrading enzymes from himenomycete Phanerochaete chrysosporium. Burds Science., 221, 661-663.

Trojanowski, J., Haider, K. \& Sundman, V. (1977) Decomposition of 14C-labelled lignin and phenols by a Nocardia sp. Arch. Microbiol., 114, 149-153. 